\title{
Determination of Some Heavy Metal Content in Tilapia and Cat Fish Species in Lake Njuwa, Adamawa State, Nigeria
}

\section{*1'IBRAHIM, D; ${ }^{2}$ IBRAHIM, AS; ${ }^{4}$ PAUL ED; ${ }^{3}$ UMAR, M; ${ }^{1}$ ZANNAH, U AS}

\author{
$I_{*}^{*}$ National Research Institute for Chemical Technology, Basawa-Zaria, Kaduna state, Nigeria. \\ ${ }^{2}$ Department of Chemistry, University of Maiduguri, Borno State, Nigeria \\ ${ }^{3}$ Ramat Polytechnic Maiduguri, Borno State, Nigeria \\ ${ }^{4}$ Department of Chemistry, A B $U$, Zaria \\ *Corresponding Author Email: thrbrhm@gmail.com
}

\begin{abstract}
Lead $(\mathrm{Pb})$, Chromium $(\mathrm{Cr})$, Copper $(\mathrm{Cu})$, Nickel $(\mathrm{Ni})$ and $\mathrm{Cadmium}(\mathrm{Cd})$ were measured in various organs (such as gills, bones and muscles) of Tilapia and Catfish collected from Lake Njuwa Adamawa state during dry season (February, 2017) and wet season (August, 2017). The results obtained were compared to permissible limits set by World Health Organization, WHO (1985), Food and Agricultural organization, FOA (2003), to ascertain its health implications. Comparison between the heavy metals concentration of dry and wet season were carried out using Mann Whitney u test, the relationship between the heavy metal concentration and the weight of the fish was carried out using Pearson correlation test. All the analysis were determined at significant level of $p>0.05$ using Microsoft excel 2010 and statistical package for social science (SPSS) 2.3. The results obtained shows that the heavy metals are more concentrated in the bones $(2.30,2.50,1.37$, and 1.40$)$ than the gills $(2.17,2.20,1.19$ and 1.23$)$ and the muscles $(0.5,0.7,0.99$ and 1.03$)$ of both the Tilapia and Catfish during the wet season than the dry season.
\end{abstract}

\section{DOI: https://dx.doi.org/10.4314/jasem.v22i8.3}

Copyright: Copyright $\odot 2018$ Ibrahim et al. This is an open access article distributed under the Creative Commons Attribution License (CCL), which permits unrestricted use, distribution, and reproduction in any medium, provided the original work is properly cited.

Dates: Received: 12 May 2018; Revised: 17 June: 2018; Accepted: 22 July 2018

Keywords: Heavy metal, Tilapia fish, Catfish, Lake, dry season, wet season

Fish is widely accepted because of its high palatability, low cholesterol and tender flesh, it is the cheapest source of animal protein and other essential nutrients required in human diet (Saduku and Olademeli, 1991). Fish may be sold and/ or affordable source of animal protein for poor house hold in urban and semi urban areas (Bene and Heck, 2005). The pollution has mainly been caused by industrial processes and industrial waste, typically from rubber and oil palm mills (Tariq et al., 1996). Heavy metals may accumulate in aquatic species, enter the food chain and cause serious harm to human health when contamination content and exposure are significant (Goyer 1997; Papagiannis et al., 2004; Turkmen et al., 2005; Fenandes et al., 2007) consequently, they have been listed by the US environmental Agency (USEPA) based on their potential for human exposure and health risk (Birungi et al., 2007). The levels of heavy metal accumulation in fish depend on the growth rate, metabolism, feeding pattern and ecological requirements of a given fish species (Yilmal et al., 2005, 2010). Another factor is the difference in life history patterns among species (including tropic and geographical distribution of life stages) which influence their exposure to heavy metal (Allen - Gil and Martynov, 1995). The harmful effect of trace metals when consumed above the recommended limit can be toxic (acute, chronic or subchronic) and heavy metals can be neurotoxic, carcinogenic, mitagenic or teratogenic. The general symptoms of human related to metal poisoning include vomiting, convulsions, paralysis, ataxia, gastrointestinal disorder, diarrhea, stomatitis, depression and pneumonia (McCluggate, 1991).

Several techniques have been used for determination of metal concentrations in fish species such as flame atomic absorption spectrometry (Abedin, 1986; ElMehdi, 1987; Ahmet, 1992; Petisleam et al., 2003; Petisleam et al., 2007), graphite furnace atomic absorption spectrometry (Sperling, 1988; Botson et al., 2004), electro-thermal atomic absorption spectrometry (Perez, 2001; Mendez, 2002), inductive coupled plasma (Chirila, 1999; Petisleam et al., 2005) and mass spectrometry (Sanchez, 2003; Petisleam et al., 2005) Different digestion methods were used as sample preparation methods for determination of heavy metals in fish samples (Olaifa et al., 2004). This study aimed to assess the concentration $(\mathrm{mg} / \mathrm{kg})$ of $\mathrm{Pb}$, $\mathrm{Cr}, \mathrm{Cu}, \mathrm{Ni}$ and $\mathrm{Cd}$ in the bones, gills and muscles of Tilapia and Catfish collected from Lake Njiwa Adamawa state during dry season (February, 2017) and wet season (August, 2017). The result obtained were then compared to permissible limits set by World Health Organization, WHO (1985), Food and Agricultural Organization, FAO (2003) to confirm its health implications.

\section{MATERIALS AND METHODS}

Sites Description: The sampling area was Lake Njuwa in south Local Government Area of Adamawa state: it 
is located between $13^{0} \mathrm{~S}$ and $14^{\circ} \mathrm{S}$ on longitude and $13^{0} \mathrm{~W}$. It has a total square area of $56 \mathrm{Km}$ being located in the North east arid zone. The different species of fish were collected from the study site of the Lake by fisher men. The entire samples were collected based on availability and choice of consumption. The collected fish samples were properly labelled, packaged and transported to the laboratory for identification, preparation and analyses.

Sample Preparation: Sampling was carried out during dry season (February, 2017) and wet season (August, 2017). Two sampling sections were selected along the Lake: Downstream and Upstream. Total of 20 individual samples were collected that is 10 during dry season (5 Catfish and 5 Tilapia fish) and 10 during wet season (5 Catfish and 5 Tilapia fish). ( $\mathrm{N}=5$ fish nets $\times 1$ day $\times 2$ sampling station $\times$ seasons). All captured fish were labelled accordingly and placed in an ice chest before transported to Scientific and Basic Research Laboratory Department, National Research Institute for Chemical Technology, Basawa - Zaria, Kaduna state, Nigeria. In the laboratory, fish samples were identified to species on standard taxonomic keys (Mohsin and Ambak, 1991; Kottelate et al., 1993). The fish were also weighed and categorized based on the two species: The Tilapia and the Catfish.

Fish Preparation: Gills, Bones and Muscles tissues of the fish was used in this study. Fish tissues were cut and oven dry at $110^{\circ} \mathrm{C}$ to a constant weight (Tuzen, 2003), after the oven dry the head of the fish was cut and the gills removed so also the fish was properly dissected to remove the existing required organ (bones) in the fish. The digestion was carried out based on the analytical methods for Atomic Absorbance Spectrometry. All the glass wares were thoroughly washed with distilled water, soaked in diluted nitric acid for 24 hours and then rinsed with distilled water. All the reagents used were of analytical grade obtained from Stevemor Chemical store, Zaria, Kaduna state, Nigeria.

Ashing: $5 \mathrm{~g}$ of each of the organ samples were weighed and put into a platinum dish, then transferred in to muffle furnace, the temperature was raised to about $55^{\circ} \mathrm{C}$ for $4-5$ hours, after the sample has turned completely in to ash, it was removed and cooled in a desiccators

Digestion of Samples: The ash prepared samples (bones, gills and muscles) were put in to $50 \mathrm{ml}$ beaker with $5 \mathrm{ml}$ of $\mathrm{HNO}_{3}$ and $5 \mathrm{ml}$ of $\mathrm{H}_{2} \mathrm{SO}_{4}$. The beaker was then placed on a hot plate and heated at $60^{\circ} \mathrm{C}$ for 30 minutes. After allowing the beaker to cool, $10 \mathrm{ml}$ of HNO3 was added and returned to the hot plate to be heated slowly at $120^{\circ} \mathrm{C}$. The temperature was increased to $150^{\circ} \mathrm{C}$, and the beaker was removed from the hot plate when the sample turned black. The sample was then allowed to cool, adding $\mathrm{H}_{2} \mathrm{O}_{2}$ until the sample become clear. The content of the beaker was transferred in to $50 \mathrm{ml}$ volumetric flask and diluted to the mark with distilled water. All the steps were performed in fume cupboard. The above procedures in this section followed the guidelines from the analytical methods for Atomic Absorption Spectrometry (Perkin Elmer, 1996).

Analysis: Concentrations of the heavy metals $(\mathrm{Cd}, \mathrm{Ni}$, $\mathrm{Cu}, \mathrm{Cr}, \mathrm{Pb}$ ) After digestion were analysed using Atomic Absorption Spectrometer (Shimazu- AAt300). The results from the AAS were expressed as $\mu \mathrm{g} / \mathrm{g}$ which was converted to $\mathrm{mg} / \mathrm{kg}$ in the results obtained. All reagents used were of analytical grade.

Statistical Analysis: The mean comparison of heavy metal concentrations among the fish species (Tilapia and Cat fish) collected in different season were carried out using Microsoft Excel and Statistical Package for Social Science, Mann-Whitney U-Test. The relationship between heavy metal concentrations among the fish species (Tilapia and Cat fish) collected in different season were carried out using Microsoft Excel: Regression and Correlation and Statistical Package for Social Science: Regression and Pearson Correlation. The relationship between the heavy metal concentrations and the weight of the fish were carried out by Pearson correlation test. All analysis was determined at significant level of $\mathrm{P}>0.05$.

\section{RESULTS AND DISCUSSION}

A total of 20 fishes were caught, 10 catfish: 5 wet season, 5 dry season. 10 Tilapia: 5 wet season, 5 dry season. In this study, however, the heavy metal permissible limits (levels) were compared with standard such as WHO (1985) and FAO (2003) to ascertain the level of toxicity of the heavy metals in the fish because it's consumed in the area. The table above shows the concentrations of chromium in the bones and muscles of Tilapia fish were not detected in both the seasons. Bones and gills have the highest concentration of $\mathrm{Pb}$ both in dry and wet season. In the dry season, bones $(2.4 \mathrm{~kg} / \mathrm{ma})$, gills $(2.19 \mathrm{~kg} / \mathrm{mg})$ and $(2.5 \mathrm{~kg} / \mathrm{mg})$ bones, gills $(2.20 \mathrm{~kg} / \mathrm{mg})$ which are all above the critical limits set by the EC (2001), WHO (1985) and FAO (2003) while the muscles both in the dry and wet season were within the permissible limits. Lead poisoning is a type of metal poisoning caused by lead in the body (WHO, 2016). Symptoms may include: abnormal pain, constipation, headaches, irritability, memory problem, inability to have children and tingling in the hands and feet (LIW, 2013). It causes about $10 \%$ of intellectual disability of otherwise unknown causes and can result in behavioural problems (WHO, 2016). Some of the effects are permanent (WHO, 2016). In severe cases anaemia, seizure, coma or death may occur (LIW, 2013; WHO 2016) causes includes exposure of lead via contaminated air, water, dust, food, consumer products (WHO, 2016). Therefore, it's not advisable 
to consume the gills and bones of the Tilapia fish obtained from Lake Njiwa Adamawa state due to the concentration of the lead above the standard permissible limits. The study found that the concentrations of $\mathrm{Cr}$ in the bones and muscles both in the dry and wet season were not detected, while the concentration of $\mathrm{Cr}$ in the gills was found to be above the critical limit set by WHO (1985). Several in vitro studies indicated that high concentrations of chromium in the cell can lead to DNA damage (Eastmond et al., 2008), therefore, it is not advisable taking the gills of the Tilapia fish from Lake Njiwa due to its health implications. In this study, heavy metal concentrations were found to be high during the wet season (August, 2017) see (Fig 1). Fish collected during the wet season had significantly higher concentration of $\mathrm{Pb}, \mathrm{Cr}, \mathrm{Cd}$, $\mathrm{Cu}$ and $\mathrm{Ni}(\mathrm{P}<0.05)$ compared to the dry season (Table 3 ). The high concentrations of heavy metals during the wet seasons can be attributed to the increases in surface run - off. Heavy rainfall leads accumulations of materials from the farm to the water bodies that is during the run- off large amount of pesticides containing heavy metal compounds are brought to the surface via run off from the near river and highly contribute to agricultural pollution, especially chemical fertilizers containing the heavy metals ( $\mathrm{Ni}, \mathrm{Pb}, \mathrm{Cu}$, e.t.c) However, several previous studies found that mean heavy metal concentrations in fish were higher in the dry season (Fufeyin 1998; Idodo-Umeli 2000; Oguzie, 2003; Obasohen and Equavoen, 2008). This is because high concentrations of metal in fish during the dry season were due to high temperature, which increases the activity, ventilation, metabolic rate and feeding seasons (Nussey et al., 2000). The low heavy metal concentrations in the wet season were due to the dilution of metal level associated with heavy rains (Obasohan and Equavoen 2008)
Table 1: Heavy metal concentration $(\mathrm{mg} / \mathrm{kg})$ of Tilapia fish collected in Dry and Wet season (Feb., and Aug., 2017)

\begin{tabular}{llllll}
\hline Samples & $\mathrm{Pb}$ & $\mathrm{Cr}$ & $\mathrm{Cu}$ & $\mathrm{Ni}$ & $\mathrm{Cd}$ \\
\hline Bones(D) & 2.30 & $\mathrm{ND}$ & 0.34 & 0.060 & 0.020 \\
Gills(D) & 2.17 & 0.70 & 0.39 & 0.050 & 0.040 \\
Muscles(D) & 0.50 & $\mathrm{ND}$ & 0.68 & 0.060 & 0.036 \\
Bones(W) & 2.50 & $\mathrm{ND}$ & 0.41 & 0.080 & 0.020 \\
Gills(W) & 2.20 & 0.72 & 0.49 & 0.070 & 0.070 \\
Muscles(W) & 0.70 & $\mathrm{ND}$ & 0.86 & 0.079 & 0.037 \\
G.M & 1.73 & 0.24 & 0.53 & 0.330 & 0.037 \\
Permissible limes(WHO,1985) & 2.00 & 0.05 & 2.00 & $0.5-0.6$ & 2.000 \\
Permissible limits(FOA,2003) & 0.20 & 0.05 & 0.20 & - & 0.050 \\
\hline Note: D=Dry season; W=Wet season; G. M= Mean of means; ND=Not detected
\end{tabular}

Table 2: Heavy metal concentration $(\mathrm{mg} / \mathrm{kg})$ of cat fish collected in dry and wet seasons (Feb, and Aug, 2017)

\begin{tabular}{llllll}
\hline Samples & $\mathrm{Pb}$ & $\mathrm{Cr}$ & $\mathrm{Cu}$ & $\mathrm{Ni}$ & $\mathrm{Cd}$ \\
\hline Bones(D) & 1.37 & 0.71 & 0.30 & 0.039 & 0.05 \\
Gills(D) & 1.19 & 0.77 & 0.40 & 0.38 & 0.09 \\
Muscles(D) & 0.99 & 0.69 & 0.50 & 0.01 & 0.04 \\
Bones(W) & 1.40 & 0.84 & 0.34 & 0.05 & 0.07 \\
Gills(W) & 1.23 & 0.86 & 0.49 & 0.05 & 0.19 \\
Muscles(W) & 1.03 & 0.82 & 0.54 & 0.03 & 0.06 \\
G.M & 1.20 & 0.78 & 0.43 & 0.04 & 0.08 \\
Permissible limits (WHO,1985) & 2.00 & 0.05 & 2.00 & $0.5-0.6$ & 2.00 \\
Permissible limits (FOA,2003) & 0.20 & 0.05 & 0.20 & - & 0.05 \\
\hline
\end{tabular}

Table 3: mean comparison of heavy metal concentrations among Tilapia fish collected in different seasons

\begin{tabular}{llllll}
\hline $\mathrm{S} / \mathrm{N}$ & $\mathrm{Pb}$ & $\mathrm{Cr}$ & $\mathrm{Cu}$ & $\mathrm{Ni}$ & $\mathrm{Cd}$ \\
\hline $\mathrm{D} 1$ & 2.30 & $\mathrm{ND}$ & 0.340 & 0.060 & 0.020 \\
$\mathrm{D} 2$ & 2.17 & 0.70 & 0.390 & 0.050 & 0.040 \\
$\mathrm{D} 3$ & 0.50 & $\mathrm{ND}$ & 0.680 & 0.060 & 0.036 \\
$\mathrm{~W} 1$ & 2.50 & $\mathrm{ND}$ & 0.410 & 0.080 & 0.020 \\
W2 & 2.20 & 0.72 & 0.490 & 0.070 & 0.070 \\
W3 & 0.70 & $\mathrm{ND}$ & 0.860 & 0.079 & 0.037 \\
P-value Excel & 0.12 & 0.42 & 0.07 & 0.00028 & 0.4037 \\
p-value SPSS & 0.86 & 0.985 & 0.540 & 0.13 & 0.55 \\
\hline
\end{tabular}

Table 4: mean comparison of heavy metal concentrations among Cat fish collected in different seasons

\begin{tabular}{llllll}
\hline $\mathrm{S} / \mathrm{N}$ & $\mathrm{Pb}$ & $\mathrm{Cr}$ & $\mathrm{Cu}$ & $\mathrm{Ni}$ & $\mathrm{Cd}$ \\
\hline $\mathrm{D} 1$ & 1.37 & 0.71 & 0.30 & 0.039 & 0.05 \\
$\mathrm{D} 2$ & 1.99 & 0.77 & 0.40 & 0.038 & 0.09 \\
$\mathrm{D} 3$ & 0.99 & 0.69 & 0.50 & 0.010 & 0.04 \\
$\mathrm{~W} 1$ & 1.40 & 0.84 & 0.34 & 0.05 & 0.07 \\
$\mathrm{~W} 2$ & 1.23 & 0.86 & 0.49 & 0.05 & 0.19 \\
$\mathrm{~W} 3$ & 1.03 & 0.82 & 0.54 & 0.03 & 0.06 \\
$\mathrm{P}-$ Value Ms-Excel & 0.008163 & 0.0128 & 0.07688 & 0.037 & 0.222 \\
p-value SPSS & 0.823 & 0.12 & 0.534 & 0.285 & 0.353 \\
\hline
\end{tabular}

Note: $\mathrm{D}=$ Dry season; Wet season
The table above shows that bones and gills of the catfish both in the wet and dry season has the highest concentrations of $\mathrm{Pb}$ but all the concentrations of the $\mathrm{Pb}$ were within the Permissible limits set by WHO (1985) and FOA (2003) testifying the safe for the consumption of the parts (Gills and the Bones including the muscles). Cr was found to be above the permissible limits set by WHO (1985) in which the bones has chromium concentration of 0.84 $\mathrm{kg} / \mathrm{mg}$, gills $0.86 \mathrm{mg} / \mathrm{kg}$ and muscles $0.84 \mathrm{~kg} / \mathrm{mg}$ during the wet seasons, so also it concentration in the dry seasons were above the set permissible limits. Therefore, due to the health effect of chromium to human as result of it accumulation it is recommended not to eat the bones, muscles and the gills of the catfish caught from Lake Njiwa Adamawa state. the $\mathrm{Cu}$ has the highest value in the muscles of 0.5 $\mathrm{mg} / \mathrm{kg}$ in the dry season and 0.54 $\mathrm{kg} / \mathrm{mg}$ in the wet seasons including the other values all falls within the permissible limits set by the WHO (1985) both the $\mathrm{Ni}$ and the $\mathrm{Cd}$ concentration in the catfish during both dry and wet seasons were found to be within the permissible limits with bones and gills has the highest concentration of $\mathrm{Ni} 0.05$ $\mathrm{mg} / \mathrm{kg}$ each in the dry and wet season while the $\mathrm{Cd}$ has the highest concentration in the gills of 0.19 $\mathrm{mg} / \mathrm{kg}$. 
The results also showed that the concentrations of the heavy metal were higher in the wet season compared to the dry season (Fig 2). Therefore, the fish collected during the wet season has significantly high concentration of heavy metal $(\mathrm{P}<0.05)$ in comparison with the obtained during the dry season (Table 4). Table 3 shows the mean comparison of heavy metal concentrations among Tilapia fish collected in different season using Ms-Excel and SPSS, the p-value of $\mathrm{pb}, \mathrm{cr}, \mathrm{cu}, \mathrm{cd}$ with the exception of $\mathrm{Ni}$ which are greater than the alpha value 0.05 implies that there is no significant difference between the heavy metal concentrations of the dry and wet season this was also proven with SPSS

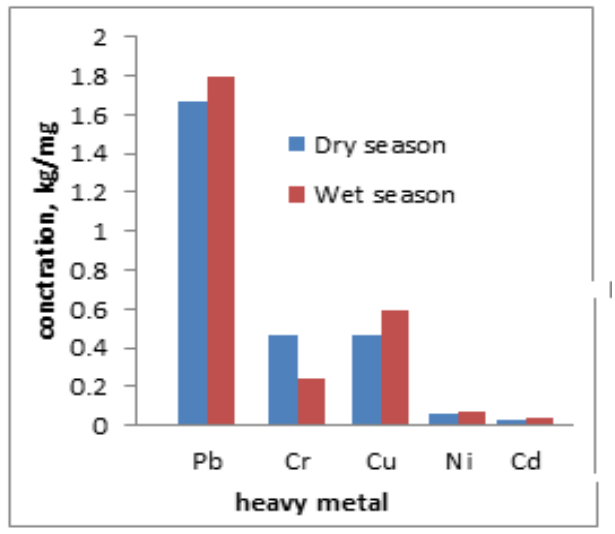

Fig 1: Tilapia fish collected in dry and wet season

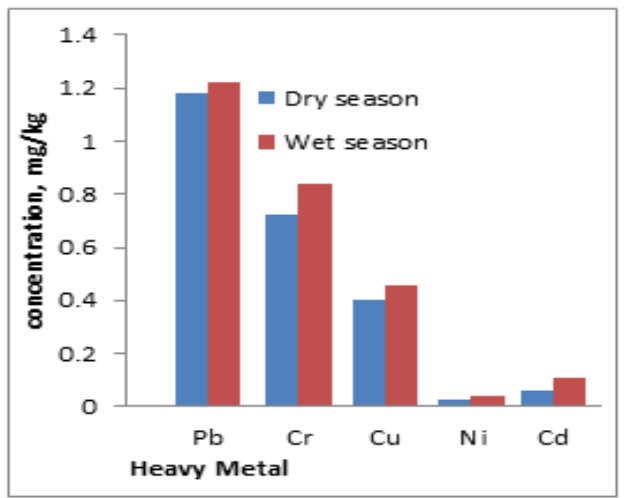

Fig 2: Catfish collected in dry and wet season

Relationship between heavy metal concentrations among tilapia fish collected in different season: Fig 3 shows that the population is normally distributed. $\mathrm{R}$ value, 0.996 of regression and correlation using Microsoft Excel signifies that, there is strong relationship between the heavy metal concentration of wet and dry season among the Tilapia fish collected in different season, this was conformed to $\mathrm{R}$ value, 0.991 of the correlation using Statistical Package for Social Science. The p-value using Microsoft Excel and Statistical Package for Social Science $1.55^{*} 10^{-15}$ and 0.00 respectively, implies that there is significant difference between the heavy metal concentration among Tilapia fish collected during dry and raining season

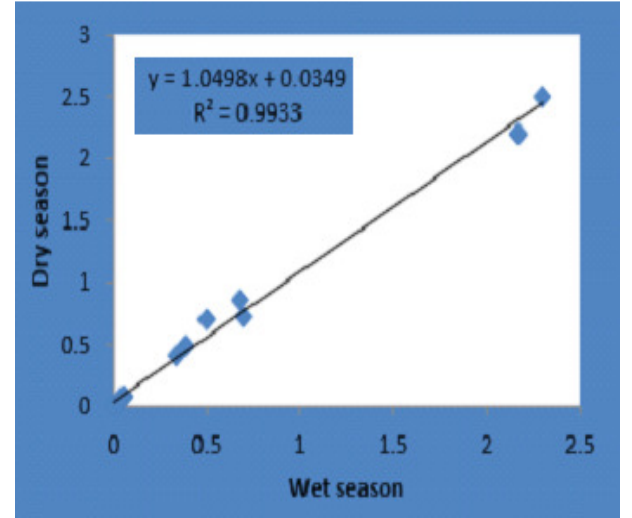

Fig 3: Relationship between dry season and wet season among Tilapia fish

The table above shows mean comparison of heavy metal concentration among Cat fish collected in different season using Microsoft excel and SPSS, which revealed the $\mathrm{p}$-value of $\mathrm{Pb}, \mathrm{Cr}, \mathrm{Ni}$ are less than the alpha value this implies that, there is significant difference between the heavy metal concentration among the cat fish collected in different season while the $\mathrm{Cu}$ and $\mathrm{Cd}$ has p-value greater than the alpha which implies that, there is no significant difference between the heavy metal concentration of $\mathrm{Cu}$ and $\mathrm{Cd}$ among the Cat fish collected in different season which agreed with the SPSS analysis

Relationship between heavy metal concentrations among cat fish collected in different season: Fig 4 shows that the population is normally distributed. The $\mathrm{R}$ value, 0.99628 of regression and correlation using Microsoft Excel signifies that, there is strong relationship between the heavy metal concentration of wet and dry season among the Tilapia fish collected in different season, this was conformed to $\mathrm{R}$ value, 0.996 of the correlation using SPSS. The p-value of Microsoft Excel and SPSS $3.27 * 10^{-15}$ and 0.00 respectively, proves that there is significant difference between the heavy metal concentration among Tilapia fish collected during dry and raining season

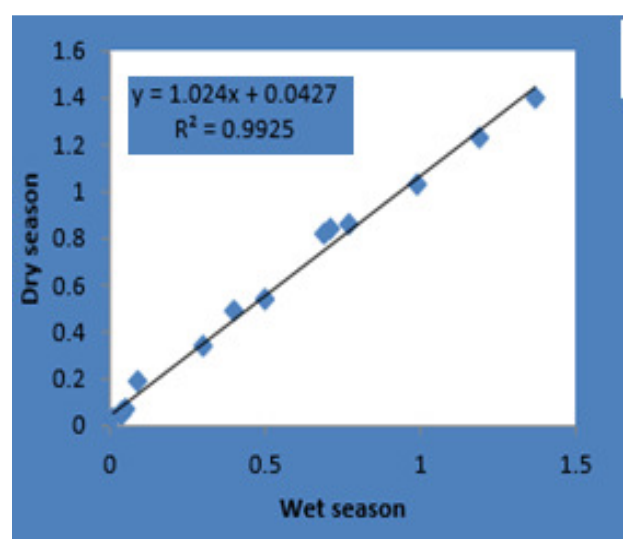

Fig 4: Relationship between dry season and wet season among Cat fish 
Relationship between Heavy Metal Concentrations and Weight Fish The significant value of the Pearson Correlation in Table5 revealed that, there is no significant relationship between the weight of the fish and the heavy metal concentrations in the fish

Table 5: correlation of metal concentration and weight of the fish

\begin{tabular}{llcc}
\hline & Weight of Fish & metal con \\
\hline \multirow{4}{*}{ Weight of Fish Pearson Correlation } & 1 & .332 \\
& Sig. (2-tailed) & & .585 \\
& N & 5 & 5 \\
\multirow{4}{*}{ metal con } & Pearson Correlation & .332 & 1 \\
& Sig. (2-tailed) & .585 & \\
& N & 5 & 5 \\
\hline
\end{tabular}

Acknowledgement: The author is thankful to National Research Insititute for Chemical Technology, Zaria, Kaduna State, Nigeria and University of Maidugiru, Borno State, Nigeria for providing research facilities and encouragement.

\section{REFREENCES}

Abedin. M. Z (1986). Atomic absorption spectrophotometric (AAS) analysis of zinc and manganese in Libyan fish and canned Tuna fish. Bulletin of Marine Biology Research Center, Libya, 7: 46-59.

Ahmet. B (1992). A case of mercury concentration in fish and human. Bulletin of Marine Biology Research Center, Libya, 9(B): 11-29.

Allen-Gil SM, Martynov V. G (1995). Heavy metal burdens in nine species of freshwater and anadromous fish from the Pechora River, northern Russia. Sci. Total Environ. 160/161:653-659.

Ashraf M.A, Maah M.J, Yusoff I, Wajid A, Mahmood K (2010). Sand mining effects, causes, and concerns: A case study from Bestari Jaya, Selangor, Peninsular Malaysia. Scientific Research and Essays. 6(6):1216-1231

Bene and Heck (2005). Distribution of metals in tissues of common carp (cyprinus carpio). Acta, vet. Borno, vol. 76, p. $93-100$

Bermejo-Barrera. P, Moreda-Pineriro. A and BermejoBarrera. A, (2001). Sample pre-treatment methods for the trace elements determination in sea food products by atomic absorption spectrometry. Talanta, 57: 969984.

Birungi Z, Masola B, Zaranyika MF, Naigaga I, Marshall B (2007). Active biomonitoring of trace heavy metals using fish (Oreochromis niloticus) as bioindicator species. The case of Nakivubo wetland along Lake Victoria. Physics and Chemistry of the Earth Parts A/B/C. 32(1518):1350-1358.
Botson. F, Dassenakis. E, Panou. E and Scoullos, M. (2004). Lead and cadmium transfer from a polluted stream to the marine environment. Rapp. Com. Int. Mer. 37: 176.

Bowen H. J. M (1979). Environmental chemistry of the elements. London: Academic Press; 1979.

Chirila. E, Birghila. S and Capota. P (1999). Biogeochemical characterization of an ecosystem using ICP-AES. SA. J. Chem. 52: 154-156.

Chouba. L, Kraiem. M, Nji Mi. W, Tissaoni. CH, Thompson. J. R and Flower. R. J (2007). Seasonal variation of heavy metals $(\mathrm{Cl}, \mathrm{Pb}$ and $\mathrm{Hg})$ in sediment and Mullet, Magil Cephalus (Mugilidat) from the Ghar Melh lagoon (Tunisia). Traditional waters Bulletin. Water Bull 4 (200), 45-52

Eastmond. Daud A, MacGregor. J. T, Slesinski. R. S (2008). "Trivalent Chromium: Assessing the Geotoxic Risk of an Essential Trace element and widely used Human and Animal Nutritional Supplement" Critival Reviews in Toxicology. 38(3): $173-190$

El-Mehdi. H. T (1987). Mercury in Bluefin Tuna fish (Thunnus thynnus) caught from Jamahiriya Coast, Bulletin of Marine Biology Research Centre, Libya, 7: 46-59.

European Commission (EC) Commission Regulation 466/2001/EC of 8 March 2001 setting maximum levels for certain contaminants in foodstuffs. Official J. European Community. 2001; 77:1-13.

Fernandez, L (2000). Low level lead exposure in an ecological factor in early life and Ecological factor in Alzhimer diseases. Epidemiology. 9(6): p. $618-621$

Food and Agriculture Organization (FAO) Heavy Metal Regulations - Faolex (2003). Legal Notice no. $66 / 2003.2003$

Fufeyin T. P (1998). Heavy metal levels in some dominant fish of Ikpoba Reservoir in Benim City, Nigeria. Environmental Review. 2:61-69.

Gledhill. M, Nimmo. M, Hill. S. J and Brown. M. T (1997). The toxicity of cooper (II) species to marine algae with particular reference to macroalgae, J. Phycology, 33: 2-11.

Goldstein. G. W (1990). Lead poisoning and brain cell function. Environ. Health Perspectives, 89: 9194.

Goyer. A. R (1997) Toxic metals and essential metal interactions. Annual review of Nutrition.17:3750 . 
Gurnham. A. S (1975). Pollutants effect on the fish of fresh water ecosystem. J. Fish Res. 11: 920-925.

Huijuan. J, Huifeng. R, Schuichi. S, Hideaki. E and Tetsuhito. H (2005). Comparison of pre-treatment condition of cadmium in fish samples and diet by microwave digestion method for ICP-AES. J. Tokyo Uni. Marine Sci. Technol. 1: 41-46.

ICP-MS with a microwave-assisted digestion treatment, Ecotoxicol. Environ. Safety. 54: 223228.

Idodo-Umeh G (2000). Freshwater fishes of Nigeria (Taxonomy, ecological notes, diet and utilization) Benin City, Nigeria: Idodo-Umeh Publishers.

Kottelat M, Whitten A.J, Kartikasari S.N, Wirjoatmodjo S (1993). Freshwater fishes of Western Indonesia and Sulawesi. Jakarta: Periplus Editions Ltd.

Lead information for workers (LIW) (2013). Achieved from the original on 18 October, 2016. Retrieved 14 October, 2016

Lenntich Water Treatment and Air Purification (2006). Water treatment, published by Lenntich, Rolterclamseweg, Netherland

Lobban. C. S and Harrison. P (1994). Sea weeds ecology and physiology. Cambridge University Press. pp. 255-282.

Malik. A (2004). Metal bioremediation through growing cells, Environ. Inter. 30: 261-278.

McCluggage D (1991). Heavy metal poisoning. Colorado, USA: NCS Magazine.

Mendez. H, Alava. F, Lavilla. I and Bendicho. C (2002). Ultrasonic extraction combined with fast furnace analysis as an improved methodology for total selenium determination in seafood by electro-thermal atomic absorption spectrometry, Analytical Chemical Acta, 452: 217-222.

Mohsin A. K. M, Ambak M. A (1983). Freshwater fishes of Peninsular Malaysia. Serdang, Selangor: Universiti Putra Malaysia.

Mohsin A. K. M, Ambak M. A (1991). Ikan air tawar di Semenanjung Malaysia. Kuala Lumpur: Dewan Bahasa dan Pustaka.

Mustafa. T (2003). Determination of heavy metals in fish samples of the middle Black Sea (Turkey) by graphite furnace atomic adsorption spectrometry, Food Chem. 80(1): 119-123.
Nussey G, Van Vuren JHJ, Du Preez HH (2000). Bioaccumulation of chromium, manganese, nickel and lead in the tissues of the moggel, Labeo umbratus (Cyprinidae), from Witbank Dam, Mpumalanga S. Africa. Water SA. 26 (2):269284.

Obasohan E. E, Eguavoen O. I (2008). Seasonal variations of bioaccumulation of heavy metals in a freshwater fish (Erpetoichthys calabaricus) from Ogba River, Benim City, Nigeria. Afr. J. Gen. Agri.4:153-163.

Oguzie F.A (2003). Heavy metals in fish, water and effluents of lower Ikpoba River in Benim City, Nigeria. Pak. J. Sci. Indust. Res. 46(3):156-160.

Olaifa. F. E, Olaifa. A. K, Adelaja. A. A and owolabia. A. G (2004). Heavy metal contamination of Clarias gariepinus from a lack and fish farm in Ibadan, Nigeria. Afr. J. Biomedical Res. 7: 145148.

Papagiannis I, Kagalou I, Leonardos J, Petridis D, Kalfakakou V (2004). Copper and zinc in four fresh water fish species from Lake Pamvotis (Greece) Environ. Inter. 2004; 30(3):357-362.

Perez. C. B, Boia. C, Pombo. L; Rebelo. E (2001). Determination of trace metals in fish species of the Ria de Aveiro (Portugal) by electro-thermal atomic absorption spectrometry, Food Chem. 75: 93100 .

Perkin Elmer (1996). Analytical methods for atomic absorption spectroscopy. USA: The Perkin-Elmer Corporation

Petisleam. I. V, Popescu. I. V, Ciupina. V and Belc. $\mathrm{M}$ (2007). Considerations regarding $\mathrm{Cu}$ and $\mathrm{Ni}$ determination from marine environmental samples of Black Sea Using FAAS,Rom. Journal of Physics. 52(3-4): 441-444.

Petisleam. T, Chirila. E and Caradima. Z (2005). Determination of $\mathrm{Cd}, \mathrm{Cu}, \mathrm{Fe}, \mathrm{Mn}, \mathrm{Pb}$ and $\mathrm{Zn}$ in marine environmental samples by ICP-MS, Rev. Chim. 56(12): 1222-1225.

Petisleam. T, Popescu. I.V, Ciupina. V and Belc. M (2003). Trace elements from marine environmental samples of Black Sea determined by atomic absorption spectrometry, Proceedings of 4th International Balkan Workshop on Applied Physics, Oviaius University Press, Constantza Romania, p. 103.

Saduku, O. and Olademili (1991). Concentration of Heavy metals in River Benue along Metropolis of Adamawa state. Department of Chemistry, Federal University of Technology, Yola 
Sanchez. F. J, Lopz. M. D, Gil Garcia. N. P, Morito. S and Martinez Vidal. I. L, (2003). Determination of heavy metals in Cray fish. J. Chem. 43: 144-149

Sanchez. F. J, Lopz. M. D, Gil Garcia. N. P, Morito. S and Martinez Vidal. I. L (2003). Determination of heavy metals in Cray fish Inter. J. (6):566-569

Sperling. K. R (1988). Determination of heavy metals in sea water and in marine organisms by graphite furnace AAS. J. Anal. Chem. 332(6): 565-567.

Tariq J, Ashraf M, Afzal M (1996). Pollution status of the Indus River, Pakistan, through heavy metal and macronutrient contents of fish, sediment and water. Water Research. 30(6):1337-1344.

Tsui M. T. K and Wang W. V. (2004). Uptake and elimination routes of inorganic mercury and methyl mercury in Daphnia Manga, Environment, Science and Technology. 38, 308-816

Türkmen A, Türkmen M, Tepe Y, Akyurt İ (2005). Heavy metals in three commercially valuable fish species from İskenderun Bay, Northern East Mediterranean Sea, Turkey. Food Chem. 91(1):167-172.
Tüzen M (2003). Determination of heavy metals in fish samples of the middle Black Sea (Turkey) by graphite furnace atomic absorption spectrometry. Food Chem. 80(1):119-123.

Waalkes M. P (2000). Cadmium carcinogenesis in review. J. Inorganic Biochem. 79(1):241-244.

World Health Organization (1992). Our planet our health: Report of World Health Organization on Health and Environment

World Health Organization (WHO) (1985). Guidelines for drinking water quality (ii): Health criteria and supporting information. Geneva: WHO. p.130.

World Health Organization (WHO) (2016). Achieved from the original on 18 October, 2016. Retrieved 14 October, 2016

Yilmaz F, Nozdemir N, Demirak A, Tuna A. L (2005) Heavy metal levels in two fish species Leuciscus cephalus and Lepomis gibbosus. Food Chem.100 (2007):830-835 